$「$ 高 DN 值磁気軸受主軸の開発と高速切削加エへの適用」にまつわる話

\title{
松下電器産業(株) 中川 亨
}

\section{1. は じめに}

磁気浮上技術の歴史をひも解くと, 1937 年に米国のホルムズ, ビームス が能動型による磁気浮上実験を試みた のが最初といわれている. 磁気的な力 で主軸を非接触で支持する磁気軸受 は, 従来軸受と比べると様々な特徵を もっている，例えば, 静圧空気軸受と 比べて, 軸受隙間を一桁以上大きくで きるために，高速回転に有利とされ る。また，制御により無限大の静剛性 が得られる。内蔵するセンサを用いて 主軸を微小量移動させるマイクロアク チュエー夕機能などを利用することも できる. 1980 年代から 1990 年代にか けて, この磁気軸受主軸を精密加工に 適用すべく，各社から開発事例が報告 された。例えば, 4 万回転の磁気軸受 主軸を用いて，アルミニウム材の高速 切削加工を可能にした開発事例が，既 に 1984 年に報告されている。しかし， 従来軸受にはない様々な特徵をもつが ゆえに当初期待された磁気軸受ではあ るが, 現在, 加工機分野で広く普及す るには至っていない.

今回, 磁気軸受の基本性能面の課題 であった軸受発熱の低減を困り, 自動 工具交換 (ATC) 対応のための磁気 軸受制御自動調整法や切削加工時の軸 振動抑制制御方法の開発を行い, 実用 面での課題解決を図った。 これが今後 の普及の一助となればと考えている。 ここでは，その開発の長い道のりを振 り返ることにしたい.

\section{2. 開発の道のり}

\section{1 開発の始まり}

1987 年の磁気軸受の原理確認を手 始めに開発をスタートした. 当初の開
発は研削加工への適用であり, 砥石周 速を飛躍的に増大させて, 研削能率や 研削比の向上を目指すというものであ った．砥石周速 $200 \mathrm{~m} / \mathrm{s}$ 以上での硝 材加工テストを実施するには至った が, 結果的には 5 自由度間の非干涉化 など基本的な技術蓄積をするにとどま った。

\section{2 磁気軸受のうまい使い方}

その後 1993 年に, 社内ニーズであ った薄片硬ぜい材料加工に適した高精 度両頭研削盤（スルーフィードグライ ンダ）の開発にあたり，砥石スピンド ルの片側に磁気軸受を用いるというア イデアが工法チームから提案された。 つまり, 縦型両頭研削盤の上下の砥石 間にワークを送り込み, 砥石間の距離 を変えることで加工厚みを制御する基 本工法に加えて, 上スピンドルに能動 型磁気軸受を用い, 浮上ギャップの一 定範囲内で浮上軸を移動させ微小切込 み機能をもたせるというものである. 加工厚みのインライン測定フィードバ ックに基づいて, 上砥石位置をバック ラッシュなく微小移動させることによ り, 砥石スピンドルの粗位置決め精 度, 砥石の摩耗, 機械の熱変位等によ り生じる加工厚みの変化を補償した。 開発機によって, 安定して加工厚み精 度 $1 \mu \mathrm{m}$ を達成するとともに, 従来の バッチ処理の両面ラッピングから連続 処理の研削加工へ切り換えることがで き, 飛躍的に生産性を向上させること ができた。そして，本加工システム は, 1997 年に栄誉ある精密工学会技 術賞を授かった。ただし, 磁気軸受スピ ンドルの基本仕様としては, 最高回転 数 $1800 \mathrm{~min}^{-1}$ で常に一定質量の砥石 を回転させるものであり,アナログ制 御仕様で汎用性の低いものであった.

\section{3 軸受発熱の問題}

時は前後するが，1995 年から研削 用ではなく高速切削加工用の磁気軸受 主軸の開発をスタートさせていた。し かし, 研削用の磁気軸受と比較して加 工負荷および加工負荷変動がともに大 きいため, 磁気軸受に求められる要求 も高く，開発は困難を極めていた。そ の中で, 先ほどのスルーフィードグラ インダの精密工学会技術賞受賞は，プ ロジェクトメンバーに勇気を与え, か つ開発の継続に重要なものとなった。

DN 值 450 万という目標は, 回転数 $50000 \mathrm{~min}^{-1}$ で加工負荷 $1000 \mathrm{~N}$ の高 速ミーリングを想定した結果であっ た. 高 DN 值の磁気軸受では, 主軸 が交番磁界を受け，いわゆる高周波加 熱されて温度上昇することは想定して いた。 しかし, 恥ずかしながらこの温 度上昇が主軸の曲がりや伸びを招き， 加工用主軸として致命的な欠陥を招く ことまで考えが及んでいなかった。工 具の振れ回りや軸の伸びが尋常ではな く，ある専門家から「こんなに振れが 大きいのによく回り続けますね」と関 心される始末であった。

とにかく, 再び磁気軸受や磁気回路 の基本に立ち返らざるをえない状況の 中で, まず, 主軸の磁束密度変化を緩 やかにできれば軸受発熱はかなり低減 できるという渦電流損に関する従来理 論をよりどころに解決策を検討してい った，その検討を加速できたのは，本 論に述べた磁気軸受の渦電流損の絶対 值を求める理論解析解の導出によると ころが大きい. この理論解析解を利用 することによって, 当時のワークステ ーションを用いた動磁場解析を非常に 効率よく進めることができ, 詳細な磁 極形状設計が可能となった。ささらに, 


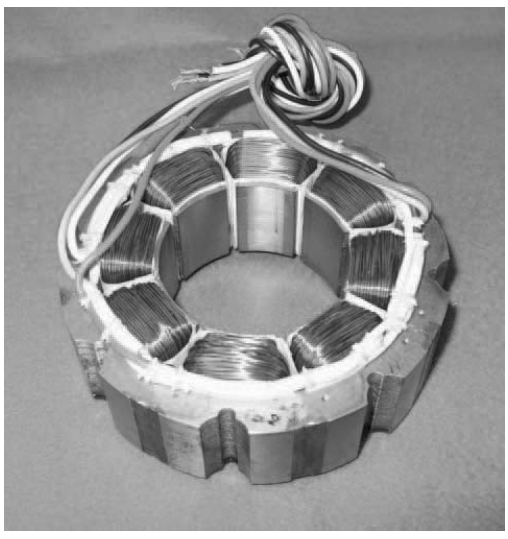

図1開発した磁気軸受電磁石 (極分割工法採用)

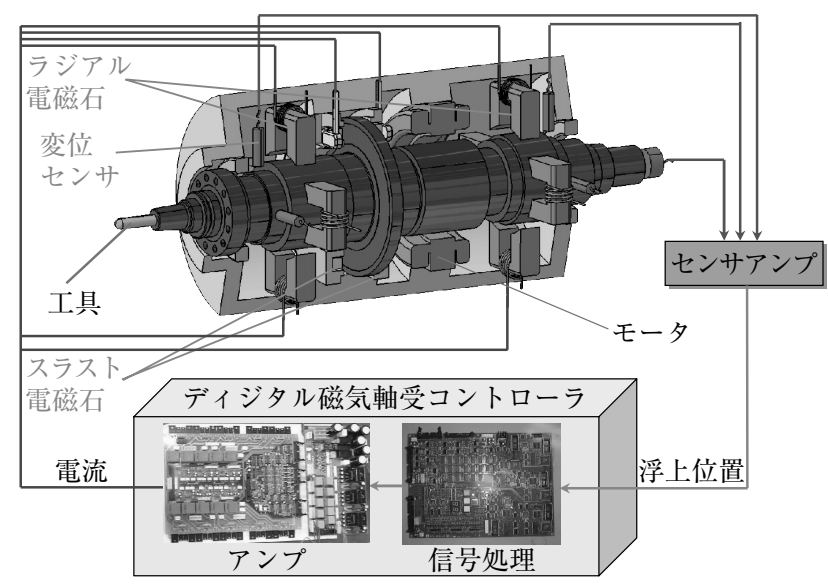

図 2 ディジタル磁気軸受コントローラ
最適設計した電磁石を具現化するため に弊社のサーボモー夕製品で用いられ ていた極分割工法（分離している磁極 1 極ずつに巻線を施した後, 磁極を接 合，結線する製造工法）を利用できた ことも幸いであった（図 1).1998 年 には，我々が直面した最も大きな課題 であった軸受発熱の大幅低減を達成し た。

\section{4 周辺技術の進歩}

それでもなお，マシニングセンタに 磁気軸受主軸を用いるためには実用面 での課題解決を図り, 沉用性も高める 必要があった。実際, ディジタル化に よる制御の多機能化やフレキシビリテ イ向上は不可欠であったため, 弊社の 産業用ロボットコントローラを参考に しつつも一からディジタル磁気軸受コ ントローラ（図2）を開発した。それ により ATC 対応のための磁気軸受制 御自動調整法や切削加工時の軸振動抑 制制御方法をソフトウエア実装するこ とが可能となった. そしてようやく 2001 年に $50000 \mathrm{~min}^{-1}$ (DN 值 450 万）仕様, 2004 年には $80000 \mathrm{~min}^{-1}$ (DN 值 384 万) 仕様の磁気軸受主軸 をマシニングセンタに搭載し，金型加 工に実戦投入した。

ディジタルコントローラの演算処理 に使用している産業用 DSP は，1980 年代にはクロック周波数 $10 \mathrm{MHz}$ 程度 であったものが, 1990 年代になると $40 \mathrm{MHz}$ に，2000 年を過ぎると 150
$\mathrm{MHz}$ 以上へと格段に能力がアップし てきた５軸の位置制御ループのサイ クルタイムを $100 \mu \mathrm{s}$ 以下にすること は容易であり，機能アップの演算を盛 り込むにも余裕のある処理能力が手軽 に得られるようになった。このよう に，磁気軸受を支えるデイジ夕ル技術 の進歩は欠かせないものであった。そ の他にも,

・高速ミーリング工法

・ エンドミル（コーテッド超硬工 具, $\mathrm{CBN}$ 工具)

. 高速回転対応の 2 面拘束ツーリ ングシステム，焼きばめ方式の 工具クランプ

・高速同期モータとドライバ

・マシニングセンタ

などの技術の進歩があってはじめて高 速ミーリング用の磁気軸受主軸の実用 化が可能となった。

\section{5 軸受特性と加工評価}

開発を通じて苦労した点に，軸受特 性と加工結果の関係を十分解明できて いなかったことが挙げられる。このこ とは, 加工用磁気軸受の制御特性や機 械特性の詳細な目標值が開発スタート 時に明確に定められないということに ほかならない。 そのため, 基本仕様を もとに磁気軸受主軸を製作し，その単 体特性評価後，いろいろな加工評価を 繰り返し，軸受特性を最適化していく 必要があった。得られた軸受特性と加 工結果の関係はまだ十分とはいえない
が，今では大きな財産となっている。 最終的に磁気軸受主軸を搭載したマ シニングセンタにより, 金型加工時間 は従来比 $2 / 3$ を達成することができ， 加工時間短縮に大きな効果が見込める ことを実証した。また，面粗さ重視の 加工条件を設定することにより，金型 の加工面品質の向上を図り，後工程の みがき時間（手仕上げ）を短縮するこ ともできる。このように，本開発機に より金型製作リードタイムをトータル で短縮でき，より速い対応力を有する 金型生産が可能となった。

\section{3.お わりに}

磁気軸受の開発を始めて 20 年にな ろうとしている。この間のマシニング センタや高速ミーリングに必要な多岐 にわたる技術の進歩，および磁気軸受 の先駆者による数多くの研究があって はじめて，本開発の磁気軸受主軸も実 用化できたと考えている。この中で, 今回, 精密工学会技術賞の栄誉を授か つたことについては甚だ恐縮する次第 ではあるが, 高速切削加工用主軸とし て今後展開していく大きな励みとした w.

最後に，開発初期段階からご指導い ただいた東京大学大学院の樋口俊郎教 授をはじめ，ご協力をいただいた多く の方々，長きにわたり開発の継続を承 諾いただいた上司に，この場を借りて 深く感謝の意を表したい 